\title{
A RATIONAL SYSTEM OF DESIGN PATENT REMEDIES*
}

\author{
Mark A. Lemley**
}

Cite AS: 17 STAN. TECH. L. REV. 221 (2013)

http://stlr.stanford.edu/rationalsystem.pdf

\begin{abstract}
A design patent owner who wins her suit is entitled to the defendant's entire profit from the sale of the product, whether or not the design was the basis for buying the product. No other IP regime has this rule, and it makes no sense in the modern world, where a design may cover only a small component of a valuable product. The culprit is section 289 of the Patent Act, a provision added in the nineteenth century, when design patents were very different than they are today. We should abolish section 289 and bring rationality to design patent remedies.
\end{abstract}

\section{TABLE OF CONTENTS}

INTRODUCTION...

I. THE ROAD TO THE ENTIRE PROFITS RULE ......................................................22

II. THE PRoBlem WITH ENTIRE PROFIT .........................................................226

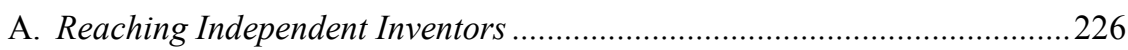

B. Designs on Components, Not Products .....................................................2230

C. Are the Parts Greater than the Sum of the Whole? ....................................233

III. WHAT IS TO BE DONE?.....................................................................................234

A. Can We Find Apportionment in Section 289? ...................................... 234

B. Limiting Profits to Near-Exact Copying......................................................2236

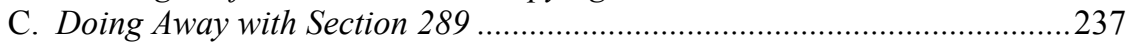

* (C) 2013 Mark A. Lemley.

** William H. Neukom Professor, Stanford Law School; partner, Durie Tangri LLP. Thanks to David Abrams, Sarah Burstein, Colleen Chien, Jim Dabney, Jason Du Mont, Rose Hagan, Peter Lee, Jessica Litman, Mark McKenna, Rebecca Tushnet, Ryan Vacca and participants at the Stanford Design Patents Conference and the Works in Progress-Intellectual Property Conference for comments on a previous draft and Rob Swanson for research assistance. 


\section{INTRODUCTION}

In the summer of 2012, a jury in San Jose, California awarded Apple the largest extant patent damages verdict in history-over $\$ 1$ billion-in its case against Samsung. ${ }^{1}$ The case attracted enormous press attention. The verdict was rightly portrayed as a big win for Apple, but also generally understood to be just one small piece in a much larger smartphone patent fight that has entangled all the companies in the industry and led to more than fifty lawsuits. While everyone agrees $\$ 1.05$ billion is a lot of money, it also seems to be just a cost of doing business for Samsung, one of many costs in a global fight that has cost nearly $\$ 20$ billion so far and shows no signs of abating. ${ }^{2}$

In one important respect, however, $\$ 1.05$ billion is not simply a cost of doing business. For the phones at issue in the case, it was the entirety of the business. $\$ 1.05$ billion wasn't a reasonable royalty on the sale of technology covered by a patent; it was measured by and arguably represented Samsung's entire profit from the products at issue in the case. ${ }^{3}$ Never mind Samsung's own patents, its engineering and design work, and the technologies of Google

1. Amended Verdict Form at 15, Apple, Inc. v. Samsung Elecs. Co., No. 5:11-cv01846-LHK (N.D. Cal. Aug. 24, 2012), ECF No. 1931. Two larger verdicts-Centocor's $\$ 1.6$ billion verdict against Abbott and Alcatel's \$1.52 billion verdict against Microsoft and others-were either reversed or reduced on appeal. See Centocor Ortho Biotech, Inc. v. Abbott Labs., 636 F.3d 1341, 1353 (Fed. Cir. 2011); Lucent Techs., Inc. v. Gateway, Inc., 580 F.3d 1301, 1340 (Fed. Cir. 2009). The Apple v. Samsung verdict was later eclipsed by the $\$ 1.2$ billion verdict in Carnegie Mellon University v. Marvell Technology Group. See Verdict Form at 6, No. 2:09-cv-00290-NBF (W.D. Pa. Dec. 26, 2012), ECF No. 762.

2. See Mark A. Lemley, Software Patents and the Return of Functional Claiming, 2013 Wis. L. REV. 905, 932 n.107 (calculating this expenditure).

3. How the jury came up with the number is, of course, unknown. Interviews with jurors after the verdict suggested they took Samsung's total revenues and multiplied by an estimated profit margin. See, e.g., Dan Levine, Velvin Hogan, Foreman in Apple Samsung Case, Says Jury Didn't Want \$1 Billion Verdict to Be Just a Slap on the Wrist, Huffington Post (Aug. 26, 2012, 3:10 PM), http://www.huffingtonpost.com/2012/08/25/velvin-hoganforeman-apple-samsung_n_1830411.html. In a post-trial ruling, by contrast, the district court concluded that the jury awarded forty percent of Samsung's profits as presented by Apple's expert. Apple, Inc. v. Samsung, Inc., 926 F. Supp. 2d 1100, 1108-09 (N.D. Cal. 2013). We don't know whether that was because they concluded that Apple had overstated those profits or because they decided it wasn't appropriate to award Samsung's entire profits. As I suggest in this Article, the latter conclusion is right as a policy matter, but wrong as a matter of law.

If the jury really awarded only forty percent of Samsung's profits, arguably the damages award under current law should have been substantially larger than it was. For bizarre historical reasons judges can't add to a jury award in federal court, though they can reduce it. Dimick v. Scheidt, 293 U.S. 474, 486-87 (1935).

Judge Koh granted Samsung's motion for a new trial on design patent profits because she concluded that Apple had shown profits for too long a period. Apple, 926 F. Supp. 2d at 1120. While a smaller amount of profits will be at issue on the retrial, if it is right that the jury awarded only forty percent of Samsung's profits the profit award on retrial may be larger, not smaller. 
and countless other inventors incorporated in the Samsung phones. The jury awarded all the profit from the sale of those phones, regardless of source, to Apple as damages. And curiously, it was Apple's product design, not any technical features, that was responsible for the overwhelming majority of the damages award. ${ }^{4}$

The jury did this because current law required it. Unlike patents on technical inventions, or for that matter copyrights or trademarks, design patent law requires that infringers - even innocent infringers - pay the plaintiff their entire profit from the sale of the infringing product, even if the design was only a small feature of that product. ${ }^{5}$

That rule, developed more than a century ago, makes no sense. As applied to a modern, multicomponent product it drastically overcompensates the owners of design patents, and correspondingly undervalues technical innovation and manufacturing know-how. It punishes even innocent infringers, particularly now that one can infringe a design patent merely on a finding that two independently developed designs are too similar to the ordinary observer. And it leaves troubling questions about what to do with all the other claimants to a share of the defendant's profits. There can be no question that the entire profits rule has to go; the only question is how to get rid of it.

I begin in Part I by discussing how we got to this unfortunate pass. In Part II, I describe the problems the entire profits rule creates for innovation and competition. I conclude in Part III by offering some suggestions for what to do about the rule.

\section{THE ROAD TO THE ENTIRE PROFITS RULE}

Patent law has always included a damages apportionment principle. While early patents tended to be on fairly simple machines or chemical inventions, ${ }^{6}$

4. See Apple, Inc. v. Samsung Elecs. Co., No. 11-CV-01846-LHK, 2012 WL 2571332 (N.D. Cal. June 30, 2012) (granting motion in limine excluding Samsung's testimony on apportionment because design patents do not permit apportionment); $c f$. Apple, Inc. v. Samsung Elecs. Co., No. 11-CV-01846-LHK, 2013 WL 412862, at*1-2 (N.D. Cal. Jan. 29, 2013) (noting that the products in question were held to infringe trade dress and utility as well as design patents and refusing to speculate what motivated the jury's calculation).

5. See, e.g., Matthew A. Smith, Design Patents § IV.A.2.a (Dec. 17, 2012) (preliminary draft), available at http://www.patentlyo.com/2012-12-17_design_patents.pdf.

6. Conflicting steamboat patents issued by different states, for instance, were one of the reasons patent law was federalized. For discussion of these conflicts, see Michael F. Martin, The End of the First-to-Invent Rule: A Concise History of Its Origin, 49 IDEA 435, 451-53 (2009); Frank D. Prager, The Steam Boat Interference 1787-1793, 40 J. PAT. OfF. SoC'Y 611, 613-15 (1958); Edward C. Walterscheid, Priority of Invention: How the United States Came to Have a "First-to-Invent" Patent System, 23 AIPLA Q.J. 263, 270 (1995). As Rob Merges has put it, "[a]t the very least, for Jefferson, if you put technology in a bag and shook it, it would make some noise." Robert P. Merges, As Many As Six Impossible Patents 
with the industrial revolution we started to patent small parts of large, multicomponent inventions like locomotives. When courts awarded damages or defendant's profits ${ }^{7}$ for infringement of those patents, they faced the problem of calculating damages attributable to the patent rather than to the defendant's product as a whole. In Garretson v. Clark, for example, the Supreme Court said the patentee "must in every case give evidence tending to separate or apportion the defendant's profits and the patentee's damages between the patented feature and the unpatented features ...."

In the nineteenth century, design patents were no different. In a series of cases involving carpet sellers, the Dobson cases, ${ }^{9}$ the Supreme Court found infringement of design patents but found no evidence allowing them to distinguish between the value of the patented design and the value of the unpatented carpet itself. As a result, the Court ultimately awarded only nominal damages of $\$ 0.06 .^{10}$

The fact that the patentee won the case but was awarded only $\$ 0.06$ incensed many in Congress. In 1887, when Congress rewrote the Patent Act, it responded to these concerns by passing a new provision addressing design patent infringement. That provision set a floor of $\$ 250$ for design patent damages, and made a defendant "further liable for the excess of such profit over and above" $\$ 250 .{ }^{11}$ Notably, the 1887 Act made defendants liable only for knowing acts of design patent infringement.

One might perhaps be inclined to read "such profit" as incorporating a principle of apportionment. But that does not appear to have been Congress's intent. In justifying the new statute, members of Congress referred to the Dobson cases, saying "[i]t now appears that the design patent laws provide no effectual money recovery for infringement.... Since that [Dobson] decision the receipts of the Patent Office in the design department have fallen off

Before Breakfast: Property Rights for Business Concepts and Patent System Reform, 14 Berkeley Tech. L.J. 577, 585 (1999). But cf. Michael Risch, America's First Patents, 64 FLA. L. REV. 1279, 1320 (2012) (discussing the surprising variety of technologies patented in the early days of the Republic, including the first U.S. patent, for a method of making ash).

7. Defendant's profits were available under the Patent Act of 1870, which provided that "the claimant shall be entitled to recover, in addition to the profits to be accounted for by the defendant, the damages the complainant has sustained thereby." Act of July 8, 1870, ch. $230, \S 55,16$ Stat. $198,206$.

8. 111 U.S. 120, 121 (1884). At the time, patent law permitted plaintiffs to recover either their damages or the defendant's profits from the infringement. Congress abolished the infringer's profits remedy in utility patent cases in 1946. Act of Aug. 1, 1946, ch. 726, § 1, 60 Stat. 778, 778 (amending the section of the U.S. Code dealing with patent remedies).

9. Dobson v. Dornan, 118 U.S. 10 (1886); Dobson v. Bigelow Carpet Co., 114 U.S. 439 (1885); Dobson v. Hartford Carpet Co., 114 U.S. 439 (1885).

10. Dornan, 118 U.S. at 18.

11. Act of Feb. 4, 1887, ch. 105, § 1, 24 Stat. 387, 387. 
upwards of 50 per cent ...."12 The House Report felt that unfair because "it is the design that sells the article" and thus the profit from that article "is not apportionable." 13 It went on to conclude that "[i]t is expedient that the infringer's entire profit on the article should be recoverable." 14 And indeed that is how courts in the nineteenth century read the statute. ${ }^{15}$

Congress wasn't too worried about the potential unfairness of the entire profit rule in 1887 because the knowledge requirement was thought to limit the scope of design patent litigation to true copyists. Representative Butterworth said that "no man will suffer either penalty or damage unless he willfully appropriates the property of another." 16 And the House Report assured us that "an innocent dealer or user is not affected." 17

The design patent damages provision exists in substantially modified form in what is now section 289 of the Patent Act. That section provides that:

Whoever... (1) applies the patented design, or any colorable imitation thereof, to any article of manufacture for the purpose of sale, or (2) sells or exposes for sale any article of manufacture to which such design or colorable imitation has been applied shall be liable to the owner to the extent of his total profit, but not less than $\$ 250 \ldots 18$

By its terms, the statute provides that design patent cases can no longer apportion damages. If you include the patented design, you must pay your entire profit to the plaintiff. And notably, the current version of the statute drops the long-standing requirement that the defendant know it was infringing. ${ }^{19}$ Like the rest of patent law, design patent infringement is now a strict liability offense. ${ }^{20}$ The Federal Circuit has required design patentees to

12. H.R. ReP. No. 49-1966, at 1 (1886), reprinted in 18 Cong. REC. 834 (1887).

13. Id. at 3 .

14. Id. (emphasis added).

15. See Untermeyer v. Freund, 58 F. 205, 212 (2d Cir. 1893) ("The manifest purpose of [C]ongress was to enlarge the remedy against infringers of design patents, and to declare that the measure of profits recoverable on account of the infringement should be considered to be the total net profits upon the whole article.").

16. 18 CONG. REC. 836 (1887).

17. H.R. REP. No. 49-1966, at 4.

18. 35 U.S.C. $\$ 289$ (2011) (emphasis added).

19. The phrase "knowing that the same has been so applied" was removed from section 289 in the 1952 Patent Act. Congress enacted a marking requirement at the same time, 35 U.S.C. $\$ 287(\mathrm{a})$, and apparently concluded that the constructive notice provided by a duty to mark design patents was an adequate substitute for the actual notice required by the law until that time. See Nike Inc. v. Wal-Mart Stores, Inc., 138 F.3d 1437, 1440-41, 1445 (Fed. Cir. 1998) (reviewing this history and concluding that "the 1952 Act can not have intended to eliminate both actual and constructive notice from liability under $\S 289$, after a century of legislative concern about notice"). But while constructive notice through marking may be effective for those who actually copy a plaintiff's design, it is not likely to help an independent inventor who may never have seen the plaintiff's design.

20. See, e.g., Florida Prepaid Postsecondary Educ. Expense Bd. v. College Savings 
"mark" their products with patent numbers, providing theoretical constructive notice to the public, ${ }^{21}$ but even independent designers are on the hook for patent infringement in modern design patent law. And if they infringe, they will be liable for their entire profit, whether attributable to the design or not.

It is worth comparing this regime to its closest analogue, trademark law. The primary remedy for trademark infringement is an injunction against continued infringement. Plaintiffs can recover damages and a defendant's profits only if they can show the defendant was a willful infringer. ${ }^{22}$ Even then, the award of profits is discretionary. ${ }^{23}$ And the statute provides that the award must amount only to "compensation" and not a "penalty." 24 Even when a court will award profits, "an accounting is intended to award profits only on sales that are attributable to the infringing conduct." 25 Copyright law too requires apportionment of profits. ${ }^{26}$

\section{The Problem with Entire Profit}

\section{A. Reaching Independent Inventors}

The 1887 Congress had in mind a very specific sort of situation: a defendant who deliberately copies a design that is at the heart of a product. Consumers buy rugs in significant part because of how those rugs look. A defendant who copies that design exactly intends to capture that value in order to compete with the plaintiff. It may be hard to distinguish exactly how much the customer values the design as opposed to the warmth the rug provides to their feet, but we are confident both that the value of the design is substantial and that the defendant knows it is; that's why she copied the design. That doesn't mean the plaintiff deserves the entire profit from the sale of the rug, but it is a reason we might put the burden on the defendant to prove the value of the noninfringing components, as we do in copyright, for instance. ${ }^{27}$ So arguably

Bank, 527 U.S. 627, 646 (1999) (holding patent infringement does not require proof of intent to infringe); Roger D. Blair \& Thomas F. Cotter, Strict Liability and Its Alternatives in Patent Law, 17 Berkeley TeCH. L.J. 799, 799 (2002) ("[P]atent law is best conceived of as a modified strict liability system ....."). In Catalina Lighting, the Federal Circuit held that knowledge was no longer a requirement for design patent infringement. Catalina Lighting, Inc. v. Lamps Plus, Inc., 295 F.3d 1277, 1287 (Fed. Cir. 2002) (finding substantial similarity on the basis of a comparison between the design patent and the accused product).

21. Nike, 138 F.2d at $1439-40$.

22. 15 U.S.C. $\S 1114$ (2011).

23. Faberge, Inc. v. Saxony Prods., Inc., 605 F.2d 426, 429 (9th Cir. 1979) ("Willful

infringement may support an award of profits to the plaintiff, but does not require one.").

24. 15 U.S.C. $\S 1117(\mathrm{a})$

25. Lindy Pen Co. v. Bic Pen Corp., 982 F.2d 1400, 1408 (9th Cir. 1993).

26. Sheldon v. Metro-Goldwyn Pictures Corp., 309 U.S. 390, 402 (1940).

27. Id. at 405 . 
the Dobson cases were wrong to put the burden of a difficult apportionment on the plaintiff.

Once we start to vary those conditions, however, the case for even a presumptive rule that the defendant's entire profit is attributable to the patent collapses. An intentional infringer might reasonably be charged with knowledge of the value of the design patent; why else did she copy it? But now that we have abandoned not only knowledge but any scienter requirement at all, we encompass within design patent infringement some number of defendants who not only designed their product independently but who could not have known they were infringing a patent. ${ }^{28}$ Not only is the moral case against punishing an innocent infringer nonexistent, but it also turns out to be quite hard to deter inadvertent conduct that couldn't have been prevented even with reasonable diligence.

The problem is worse than that, however, because the Federal Circuit has recently changed the law of design patent infringement in ways that make it even more likely that the law will ensnare innocent infringers. ${ }^{29}$ Unlike standard "utility" patents covering inventions, which are defined by the language of written claims, design patents covering new ornamental features of an object are typically defined by drawings or photographs of the patentee's design. ${ }^{30}$ The basic test for infringement of a design patent is the "ordinary observer" test, which assesses "whether an ordinary observer, familiar with the prior art, would be deceived into thinking that the accused design was the same as the patented design." 31 But that test has long been supplemented by a requirement that the defendant must have appropriated the point of novelty of the invention. ${ }^{32}$ If the defendant's use didn't include the novel feature or features in the patentee's design, it couldn't infringe.

In 2008, in Egyptian Goddess, Inc. v. Swisa, Inc., the Federal Circuit changed the law of design patents to eliminate the point-of-novelty test for infringement. ${ }^{33}$ The court worried that a focus on the point of novelty would confuse factfinders, particularly in the subset of cases in which the patentee's invention was a combination of existing features rather than the development of

28. Indeed, some patentees are now using patent continuations to extend their patent rights to cover third party designs that were not infringing at the time they were made. See Perry J. Saidman, The Crisis in the Law of Designs, 89 J. PAT. \& Trademark Off. Soc'y 301, 319 (2007) (referring to this as "standard and well-accepted patent gamesmanship").

29. Portions of this section are adapted from Mark A. Lemley, Point of Novelty, 105 Nw. U. L. REV. 1253 (2011).

30. Design Patent Examining Procedures, 37 C.F.R. $§ 1.153$ (2012); Mary Bellis, Design Patent: The Importance of Great Drawings and Correct Formatting, ABout.com, http://inventors.about.com/od/designpatents/a/design_patent_f_4.htm (last visited Dec. 5, 2013).

31. 543 F.3d 665, 672 (Fed. Cir. 2008) (en banc).

32. Id. at 670-71.

33. Id. at 678 . 
a new one. ${ }^{34}$ Novelty still matters, but now only as a defense that must generally be assessed separately from infringement. ${ }^{35}$ And subsequent Federal Circuit cases have used Egyptian Goddess as precedent in concluding that point of novelty is no longer the test for the invalidity of a design patent either. ${ }^{36}$

Think about this for a minute. It is no longer the law that to infringe, the defendant must incorporate the very thing that makes the patented invention patentable. As long as an ordinary observer would confuse the two products, the fact that that confusion arises from similarities that already exist in the prior art doesn't defeat a finding of infringement. It might or might not create a defense that the patent is invalid for anticipation, though again that seems to depend on what an ordinary observer would think when comparing the patented design and the prior art. ${ }^{37}$ And the doctrines that tend to drive invalidityfunctionality and nonobviousness - have much less application in design patents than elsewhere in IP. ${ }^{38}$

The Federal Circuit did express concerns with how the point-of-novelty test worked as applied to patents on combinations. And the court took some steps to try to sneak back in the prior-art comparison it had just rejected, declaring that the ordinary observer was henceforth one who was "familiar with the prior art." 39 So one reasonable reading of the case is that the court intended

34. Id. at 677.

35. See id. at 678 .

36. See, e.g., Int'l Seaway Trading Corp. v. Walgreens Corp., 589 F.3d 1233, 1237-38 (Fed. Cir. 2009). For a discussion of this extension, see Marta Kowalczyk, Recent Developments, Design Patent Infringement: Post-Egyptian Goddess, 2010 U. ILL. J.L. TeCH. \& POL'Y 239, 250-56. For an argument that Egyptian Goddess was generally correct, and that we should stop evaluating obviousness of design patents in favor of an ordinary observer standard, see Janice M. Mueller \& Daniel Harris Breen, Overcoming the "Impossible Issue" of Nonobviousness in Design Patents, 99 Ky. L.J. 419 (2011). But see Craig Zieminski, A Function for Markman Claim Construction in Design Patents, 90 J. PAT. \& TRADEMARK OfF. SoC'y 326 (2008) (arguing, before Egyptian Goddess, that claim construction was necessary to separate unprotectable functional elements in designs; Egyptian Goddess rejected that argument).

37. See Int'l Seaway, 589 F.3d at 1237-38.

38. See, e.g., Revision Military, Inc. v. Balboa Mfg. Co., 700 F.3d 524, 526-27 (Fed. Cir. 2012) (rejecting the district court's focus on functional aspects of the plaintiff's design); Mark P. McKenna \& Katherine Strandberg, Progress and Competition in Design, 17 STAN. TECH. L. REV. 1 (discussing the limited use of functionality in design patent law); Michael Risch, Functionality and Graphical User Interface Design Patents, 17 StAn. TeCH. L. Rev. 53 (discussing the cramped reading of obviousness in design patents).

It was not always the case that functionality had such a limited role in design patent law. As Judge Giles Rich, a principal drafter of the 1952 Act, told Congress in 1987, "the great bulk of industrial design is simply not protectable by design patents" because it was functional, not ornamental. Industrial Innovation and Technology Act: Hearings on S. 791 Before the Subcomm. on Patents, Copyright and Trademarks of the S. Comm. on the Judiciary, 100th Cong. 8-9 (1987).

39. Egyptian Goddess, 543 F.3d at $677,681$. 
not to make the point of novelty irrelevant but simply to change the burden of proof on whether the defendant appropriated the novelty of the patentee's invention. ${ }^{40}$ This concern with the appropriate burden of proof is similar to what motivates the court to reject the practicing-the-prior-art defense in utility patent cases $^{41}$ : defendants shouldn't be able to turn a defense that they must prove by clear and convincing evidence into something that the plaintiff must prove by a preponderance of the evidence. ${ }^{42}$

But if avoiding burden shifting was the court's goal, Egyptian Goddess arguably went too far. Whatever the legal standard, we don't want patentees suing defendants who do no more than practice the prior art. When a jury rather than a judge is the factfinder and the law discourages dissecting the patented invention to exclude the unprotectable elements, there is a very real risk that a design patent can now be infringed even by a product that lacks the new feature encompassed by the patent as long as an ordinary observer would think the two were substantially the same overall. ${ }^{43}$ The possibility of invalidity is cold comfort, given the low threshold for obviousness in design patents and the high burden of proof.

Whether or not Egyptian Goddess is the right rule as a matter of substantive design patent law, the clear effect of the new rule has been to throw infringement cases to the "ordinary observer" test with less emphasis on copying the novel feature of the invention. That means that independent inventors are at greater risk of being found liable for infringement than before. And because of section 289, even a defendant who "infringes" a design patent only by including features also present in the prior art will have to pay its entire profit to the patentee. That can't serve either a moral or a deterrence goal.

40. See id. at 678-79. In a later case, Revision Military, the court emphasized the role of the prior art as a "frame of reference" for applying the ordinary observer test, and chastised the district court for failing to consider the prior art. $700 \mathrm{~F} .3 \mathrm{~d}$ at 527.

41. See, e.g., Kinetic Concepts, Inc. v. Blue Sky Med. Grp., Inc., 554 F.3d 1010, 1025 (Fed. Cir. 2009) ("“[P]racticing the prior art' is not a defense to patent infringement.").

42. The justification for a clear and convincing evidence standard-already weak for utility patents, see Doug Lichtman \& Mark A. Lemley, Rethinking Patent Law's Presumption of Validity, 60 STAN. L. REV. 45, 59-61 (2007) - is even weaker for design patents, which are generally issued in overwhelming numbers without any substantive rejection or amendment. See Dennis Crouch \& Jason Rantanen, Design Patent Rejections, PATENTLY-O (Jan. 19, 2010, 2:53 AM), available at http://www.patentlyo.com/patent/2010/ 01/design-patent-rejections.html (finding that more than $80 \%$ of design patents issue without any initial rejection or amendment, compared with $13 \%$ of utility patents, and that only $1.2 \%$ of all design patent applications have a prior art rejection).

43. It is particularly problematic because, as Rebecca Tushnet has pointed out, we parse images differently than we do words, and we may be less good at separating the old from the new in a composite image. Rebecca Tushnet, The Eye Alone Is the Judge: Images and Design Patents, 19 J. InTell. Prop. L. 409 (2012); Rebecca Tushnet, Worth a Thousand Words: The Images of Copyright, 125 HARV. L. REV. 683 (2012). 


\section{B. Designs on Components, Not Products}

Further, the congressional assumption in 1887 that "it is the design that sells the article" 44 may well be true of carpets, but it is surely not true of all design patents. True, the classical design patent covers the design of the entire product. But not all design patents cover an entire product. Here is one of Apple's many design patents on its iPhone. ${ }^{45}$

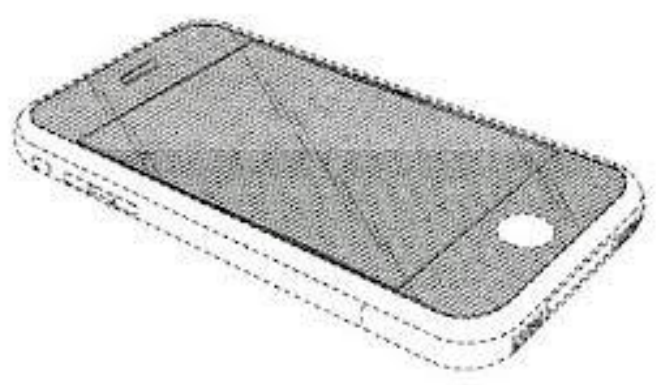

The claim covers only the portion in solid rather than dotted lines, so it covers only the black, flat front face of the phone.

Here is another Apple iPhone design patent. ${ }^{46}$

U.S. Patent Oct. 2, 2012 US D668,263 S

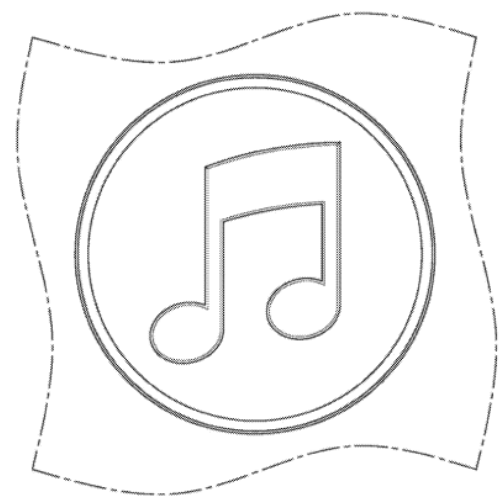

44. H.R. REP. No. 49-1966, at 3 (1886), reprinted in 18 CONG. REC. 834 (1887).

45. U.S. Patent No. D618,677. fig.1 (filed Nov. 18, 2008).

46. U.S. Patent No. D668,263. fig.1 (filed Oct. 8, 2010). 
It is (barely) possible to argue with a straight face that it is the shape and overall design of the iPhone that causes consumers to buy it. It's not even remotely plausible that the shape of the Apple iTunes icon is what causes people to buy the iPhone, particularly when none of the patents Apple asserted cover the entire phone rather than discrete parts. And while these two patents happen to be owned by the same company, there is no reason to think that will always be true. And it literally cannot be the case that both the phone shape patent and the iTunes icon patent are the sole cause of the consumer buying the phone.

There are plenty more design patents that cover the same product; here are a couple. ${ }^{47}$
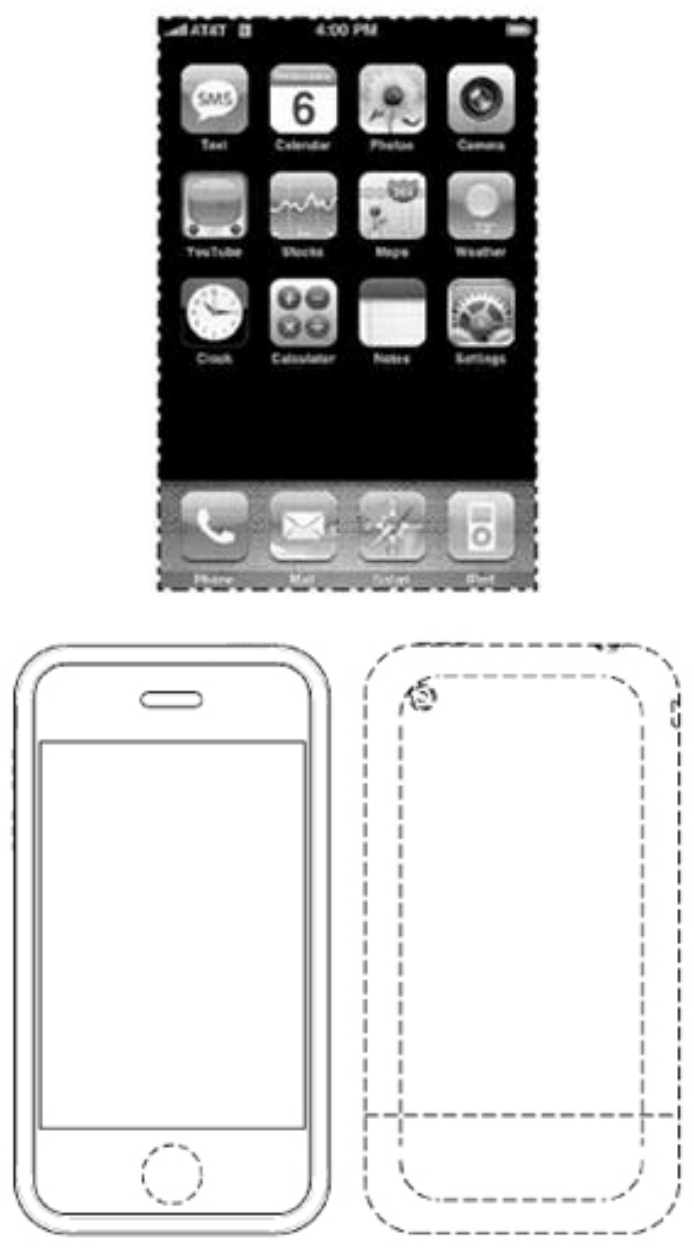

47. U.S. Patent No. D604,305 fig.1 (filed June 23, 2007) (top); U.S. Patent No. D593,087 fig.3, fig.4 (filed July 30, 2007) (bottom). 
More generally, it's safe to say that the world is more complex than it was in 1887 , and so are products. The likelihood that a product has more than one patented design is much greater than it was in 1887, particularly given the notorious laxity of the PTO in granting design patents in recent years. ${ }^{48}$ Virtual designs on things like icons are particularly likely to overlap, and there are more and more of them. ${ }^{49}$ And if there is more than one patented design in a product, the syllogism that the design patent drives the sale of the product falls apart.

Nor does all the value of a product come from design patents. People don't buy iPhones simply because they look cool; they buy them because they function. ${ }^{50}$ Those functions are both of intrinsic value and are subject to many utility patents. Indeed, by one estimate there are 250,000 patents that arguably

48. For criticism of this laxity, see Ryan Vacca, Design Patents: An Alternative When the Low Standards of Copyright Are Too High?, 31 S. ILL. U. L.J. 325 (2007) (criticizing the PTO for granting patents on things like blank forms that even the copyright office would refuse to register); Dennis D. Crouch, A Trademark Justification for Design Patent Rights 7, (Aug. 10, 2010) (unpublished manuscript), available at http://papers.ssrn.com/sol3/papers. cfm?abstract_id=1656590 (finding that the PTO issued 98\% of design patent applications without ever challenging inventiveness, and calling design patent law a "de facto registration system"). A particularly notorious example is Apple's (still valid) patent on the rectangle, U.S. Patent D504,889 fig.1 (filed Mar. 17, 2004):

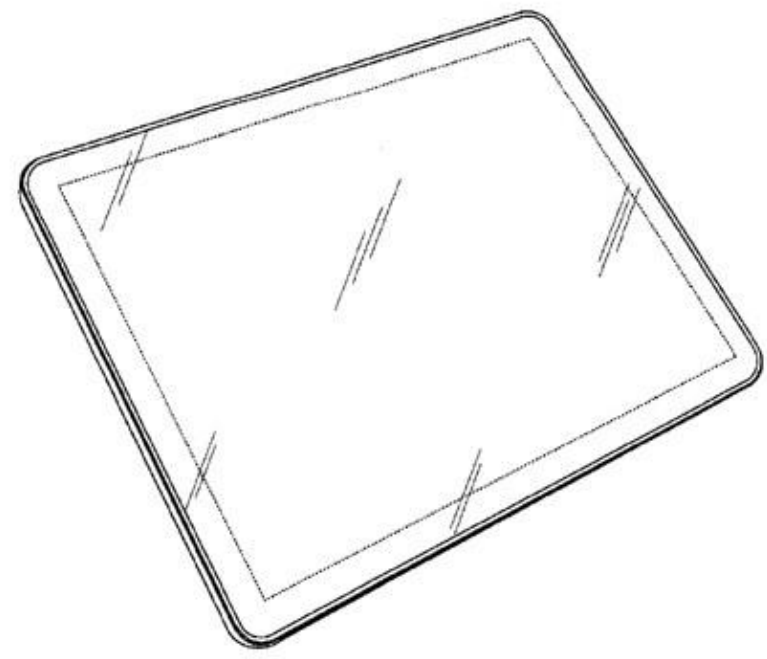

49. Jason J. Du Mont \& Mark D. Janis, Virtual Designs, 17 Stan. Tech. L. Rev. 107 (documenting the growth of virtual design patents).

50. Design patents are not supposed to protect the functional aspects of a product, though the law in this area is murky. For discussion, see generally Jason J. Du Mont \& Mark D. Janis, Functionality in Design Protection Systems, 19 J. InTell. Prop. L. 261 (2012); Risch, supra note 38. 
cover various aspects of a smartphone. ${ }^{51}$ To conclude that one design patent drives the purchase of the product, and therefore that all the defendant's profit is attributable to infringing that patent, is to say that none of those other contributions should be valued at all. The closest analogy in patent law is the problematic "entire market value rule," under which a patent owner can win lost profits from sales it would made of an entire product if it can show that the patent is the basis for demand of the product. ${ }^{52}$ But for most products (excluding, say, fashion) it is more plausible that a functional feature in a utility patent drives demand than that a patented design does. ${ }^{53}$ And even the entire market value rule requires a utility patent owner to prove that the patent was the basis for market demand, ${ }^{54}$ something section 289 does not. The assumption that underlies section 289, then, doesn't seem plausible in the modern world.

\section{Are the Parts Greater than the Sum of the Whole?}

Suppose a design patentee wins a design patent suit based on a component patent. What happens then? There are other patentees - utility and perhaps design - waiting in the wings who want to claim a piece of this pie. What should be done about them? The defendant can't pay out its profit; it has already done that. Maybe we should allow the poor defendant to implead the design patent plaintiff in all subsequent litigation, on the theory that they hold the money that the second plaintiff now claims belongs in whole or in part to them. So the next time Samsung gets sued by a patent troll, maybe they should be able to point to Apple and say "they've got all the money; go collect it from them." That sounds absurd, but then so does ordering payment of all the money

51. See David Drummond, When Patents Attack Android, Google Official Blog (Aug. 3, 2011), http://googleblog.blogspot.com/2011/08/when-patents-attack-android.html (statement of David Drummond, Chief Legal Officer at Google).

52. For discussion and criticism of this rule, see, for example, Mark A. Lemley, Distinguishing Lost Profits from Reasonable Royalties, 51 WM. \& MARY L. REV. 655 (2009); Brian J. Love, Patentee Overcompensation and the Entire Market Value Rule, 60 StAN. L. REV. 263 (2007). Courts sometimes misunderstand this rule; one prominent Federal Circuit decision confused the entire market value rule-under which the patentee can recover for the sale of an entire product by showing it would have made that sale but for infringement of a specific component - with the royalty base, which is the denominator of defendant's sales used to set a royalty percentage. Lucent Techs. v. Gateway, Inc., 580 F.3d 1301, 1336-40 (Fed. Cir. 2009) (making this error).

53. Indeed, because design patents are not supposed to cover functional products, by definition a design patent is valid only if there are numerous available alternative designs. If that isn't true - if the design is the thing that makes the product valuable - it is arguably functional and should be protected, if at all, only by a utility patent. $C f$. Mark A. Lemley \& Mark P. McKenna, Is Pepsi Really a Substitute for Coke? Market Definition in Antitrust and IP, 100 GEO. L.J. 2055 (2012) (arguing that IP rights confer market power more often than courts recognize).

54. Uniloc USA, Inc. v. Microsoft Corp., 632 F.3d 1292, 1318 (Fed. Cir. 2011). 
in the first place. ${ }^{55}$ While multiple claims to the same profit are not unknown in remedies law, we generally require some form of division of profits or establish a hierarchy of rights to the same piece of property. ${ }^{56}$ And where we don't, it is because the defendant's intentional misconduct caused the injury to multiple parties. ${ }^{57}$ The fact that we may have multiple parties lining up, each entitled to collect the defendant's entire profit, points up the oddity of the law as it currently stands.

\section{WHAT IS TO Be DONE?}

Barring some legislative fix, we are stuck with a world in which the owner of any design patent would seem under the statute to be entitled to the entire profits from the sale of the defendant's product. The problem is simple: for idiosyncratic historical reasons we don't do apportionment in design patents. ${ }^{58}$ But we should. The question is how to achieve that result.

\section{A. Can We Find Apportionment in Section 289?}

One approach would focus on the language of the statute as a whole. Section 289 currently reads in its entirety:

Whoever during the term of a patent for a design, without license of the owner, (1) applies the patented design, or any colorable imitation thereof, to any article of manufacture for the purpose of sale, or (2) sells or exposes for sale any article of manufacture to which such design or colorable imitation has been applied shall be liable to the owner to the extent of his total profit, but not less than $\$ 250$, recoverable in any United States district court having jurisdiction of the parties.

Nothing in this section shall prevent, lessen, or impeach any other remedy which an owner of an infringed patent has under the provisions of this title, but he shall not twice recover the profit made from the infringement. ${ }^{59}$

55. See Thomas F. Cotter, Reining in Remedies in Patent Litigation: Three (Increasingly Immodest) Proposals, 29 SANTA Clara COMP. \& High TeCH. L.J. (forthcoming 2013) (manuscript at 18) (describing section 289 as "out of step with the rest of the world and-more importantly-with economic rationality").

56. See, e.g., Sheldon v. Metro-Goldwyn Pictures Corp., 309 U.S. 390 (1940) (apportioning profits in a copyright case).

57. See Douglas Laycock, Modern American Remedies 653 (4th ed. 2010) (explaining that plaintiffs are limited to recovering the fair market rental value in cases of innocent conversion of property).

58. One commentator described the rationale for leaving design patent profits as a remedy when utility patent profits were eliminated in 1946 as "unclear," and suggested that the real explanation may have been nothing more than "inadvertence." Caprice L. Roberts, The Case for Restitution and Unjust Enrichment Remedies in Patent Law, 14 LEwIS \& Clark L. ReV. 653, 660 n.47 (2010).

59. 35 U.S.C. $\S 289$ (2011). 
As noted above, this language is derived in part from the 1887 Act. But the language itself contains ambiguities that should arguably be resolved in favor of apportionment. The language says a defendant is "liable to the owner to the extent of his total profit." Read literally, there is no requirement in that language that the profit be the profit from the sale of the infringing product at all. If United Airlines uses a patented part in one of its planes, can the patent owner simply point to that infringement and say, "Now I am entitled to the entire profit from all aspects of United Airlines"? 60 Of course not. As Judge Posner put it in the copyright context, a plaintiff must do more than simply attach the defendant's income tax return to the complaint and say it wants all the money. ${ }^{61}$ The general principle of remedies law requires a plaintiff to show some connection between the profits and the infringement, even though nothing in the statutory language expressly imposes such a requirement. Indeed, in one early case in which the defendant sold refrigerators that had door latches that infringed the plaintiff's latch patent, the court refused to grant profits on the refrigerators themselves, instead defaulting to the $\$ 250$ statutory minimum because the intermediate good (the latch) was not sold separately. ${ }^{62}$ But the plaintiff in that case apparently didn't seriously contend it was entitled to the entire profit on the refrigerator, so it is of limited help in establishing the connection required between the design and the profits. The court does, however, assume that there must be some such connection.

"Some connection" isn't necessarily apportionment. But here the final paragraph of section 289 may guide us. That provision prohibits double counting of the defendant's profits and the plaintiff's losses. In the course of defining "double counting," it refers to the defendant's profits measure as "the profit made from the infringement." 63 That clearly seems to contemplate some kind of apportionment: the profit at issue in a design patent case is not the defendant's total profit, or even defendant's total profit from a single product, but the profit "made from"- that is, causally derived from-"the infringement."

But what of the legislative history from the 1887 Act, which seemed to reject the idea of apportionment? For some judges - those committed to fidelity

60. OK, bad example.

61. Taylor v. Meirick, 712 F.2d 1112, 1122 (7th Cir. 1983) (Posner, J.) ("If General Motors were to steal your copyright and put it in a sales brochure, you could not just put a copy of General Motors' corporate income tax return in the record and rest your case for an award of infringer's profits.”).

62. Young v. Grand Rapids Refrigerator Co., 268 F. 966, 973-74 (6th Cir. 1920). The court made clear that the $\$ 250$ penalty was for the entire infringement, not per article. A $\$ 250$ per article floor on profits in 1887 would have made no sense. See also Bush \& Lane Piano Co. v. Becker Bros., 222 F. 902, 904-05 (2d Cir. 1915) (profits from infringement of design patent on a piano case were limited to profits on the sale of the case, not the piano).

63. 35 U.S.C. $\S 289$. 
to statutory text regardless of legislative intent- the question won't matter. The fact that the modern statute seems to invoke apportionment will be enough. But even judges who pay attention to legislative history should hesitate to apply it here. Not only does it lead to a nonsensical result, but it seems predicated on two assumptions: that the design is the basis for purchasing the product, and that only intentional copiers will be liable for their profits. Those assumptions may have made sense 150 years ago, but they no longer do. Designs still sell some products, but design patents now cover attributes of many products far more complex than those contemplated by Congress in the nineteenth century. And section 289 has been amended to remove the requirement of intentional infringement. So Representative Butterworth's assurance that "no man will suffer either penalty or damage unless he willfully appropriates the property of another," 64 true in 1887 , is true no longer. Today a company could act in perfect good faith in adopting a similar design as a small aspect of a much larger product and still be forced to disgorge its entire profits from the product. Judges who believe in legislative history do so because they think it illuminates Congressional intent. Here, what legislative history we have suggests Congress would not have intended that result. 65

\section{B. Limiting Profits to Near-Exact Copying}

A second approach would be to read the reference in section 289 to "the patented design, or any colorable imitation thereof" to be limited to a subset of design patent infringement cases. The legal standard for design patent infringement is whether "the accused design is substantially the same as the claimed design. The criterion is deception of the ordinary observer, such that one design would be confused with the other." 66 "Colorable imitation," by contrast, seems narrower; it implies either an act of copying or at least that the two designs are so close that one seems a counterfeit of the other. And indeed the Supreme Court held in the nineteenth century that the use of that term in trademark law referred only to marks "which require[] careful inspection to distinguish the spurious trade mark from the genuine." 67 So perhaps section 289 applies not to all design patent cases, but only to the most egregious ones - cases in which the defendant actually adopted the plaintiff's

64. 18 CONG. REC. 836 (1887).

65. It is true that Congress abolished infringer's profits as a remedy in utility patents in 1946, but left it intact for design patents. As noted above, not changing the law for design patents may have been inadvertent in 1946. See supra note 58. Even if it was deliberate, though, design patent law in 1946 still required proof of intentional infringement. And it was not until 1952 that Congress made the changes to section 289 that I discuss in text.

66. L.A. Gear, Inc. v. Thom McAn Shoe Co., 988 F.2d 1117, 1124 (Fed. Cir. 1993).

67. McClean v. Fleming, 96 U.S. 245, 255 (1878). 
design or one sufficiently close that it is a colorable imitation of that design. ${ }^{68}$

That approach would minimize the harm done by section 289 , and bring it closer to the situation contemplated by Congress in 1887. But it would require courts to assess two different standards of design similarity. ${ }^{69}$ It may be an uphill battle after Already, LLC v. Nike, Inc., where the Supreme Court read a covenant not to sue that extended to "colorable imitations" to reach broadly, covering anything that might infringe the asserted trademark. ${ }^{70}$ And it would still leave many cases in which defendants pay far more than logic dictates they should. After all, even an exact copy of the iTunes music icon still isn't responsible for all Samsung's profits on the sale of a smartphone.

\section{Doing Away with Section 289}

A final possible solution is simple: change the statute. Section 289 is an anomaly, a holdover from a time when we both granted defendant's profits as a general measure of patent damages and required proof of knowing infringement. We don't need it. If we just got rid of it, design patent damages would operate just like utility patent damages — offering lost profits, but in no event less than a reasonable royalty, to prevailing plaintiffs. ${ }^{71}$ That means apportionment. Would that lead to Dobson-style undercompensation? I doubt it. Courts in copyright and utility patent cases have managed complex apportionment cases pretty well when they actually apply the doctrine, andunlike Dobson - they put the burden of proof on the defendant, not the plaintiff. ${ }^{72}$ So the makers of rugs - for whom the design really is a major part of the product's value — can and should be protected against incorrect rulings

68. Cf. Trans-World Mfg. Corp. v. Al Nyman \& Sons, Inc., 750 F.2d 1552, 1567 (Fed. Cir. 1984) ("[S]ection 289 was intended to permit recovery of an infringer's profits only in cases where the infringement involved sale of a product embodying the patented design.") (emphasis added).

69. This is not necessarily a debilitating objection. Courts must already do that in determining whether a trademark defendant is an ordinary infringer or a counterfeiter to whom different remedies apply. 18 U.S.C. $\S \S 2318,2320$.

70. 133 S. Ct. 721, 728 (2013) ("“[I]t is hard to imagine a scenario that would potentially infringe [Nike's trademark] and yet not fall under the Covenant.'... [T] he covenant encompasses all of its allegedly unlawful conduct....”) (quoting Nike, Inc. v. Already, LLC, 663 F.3d 89, 97 (2d Cir. 2011)).

71. 35 U.S.C. $\S 284$ (2011). While courts occasionally refer to section 289 as setting out the statutory basis for infringement, in fact section 271 sets out the rules for infringement of any patent, including a design patent. The general provisions of title 35 apply to design patents except as provided in 35 U.S.C. $\S \S 171-74$. Section 289 merely sets out specific requirements for obtaining defendant's profits. See, e.g., Braun, Inc. v. Dynamics Corp., 975 F.2d 815 (Fed. Cir. 1992) (applying section 289 only in determining remedies, not infringement).

72. See, e.g., Sheldon v. Metro-Goldwyn Pictures Corp., 309 U.S. 390, $402-04$ (1940); Grain Processing Corp. v. Am. Maize-Prods. Corp., 185 F.3d 1341, 1349 (Fed. Cir. 1999). 
like the one in Dobson. And where the design is really the thing that drives the sale of the product, patentees may even be able to recover the entire value of the lost sale under the "entire market value rule." 73 That may happen more often in design patents than elsewhere; here are some examples of recentlyfiled design patent suits: ${ }^{74}$

- Patent No. D624,501 covers a dual USB adapter owned by Ever Win International. Ever Win's product is available from Amazon for \$20 and is allegedly being infringed by similar devices being sold at CVS and other locations.
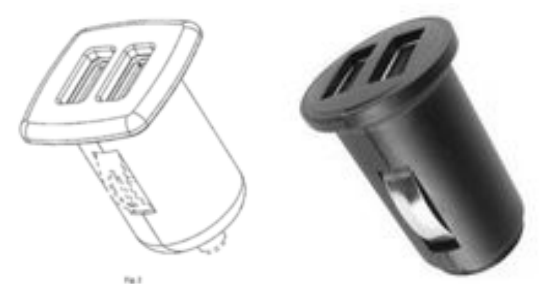

- Mr. BD Kidd has sued Home Depot and others for infringing his Patent No. D646,537 covering a crimping tool that fits in your pocket.

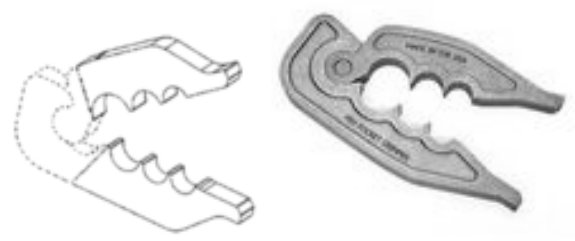

- Nebo's No. D659,869 covers these funky flashlights that are allegedly being infringed.
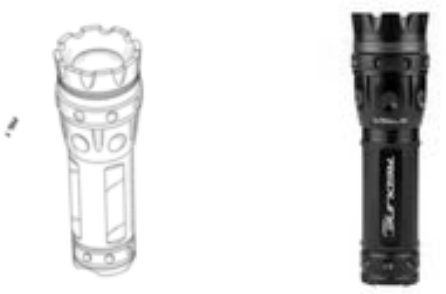

73. The entire market value rule is a rare device in patent damages that allows patentees to recover not just the value of infringing contributions, but the value of noninfringing products that would have been sold along with the infringing ones. It is available only where the patented invention is itself the thing that makes consumers buy the product. See, e.g., King Instruments Corp. v. Perego, 65 F.3d 941, 956-57 (Fed. Cir. 1995). For discussion of the doctrine, see generally Lemley, supra note 52; Love, supra note 52.

74. Dennis Crouch, Recent Design Patent Litigation, PAtently-O (Dec. 23, 2012, 9:08 PM), available at http://www.patentlyo.com/patent/2012/12/recent-design-patentlitigation.html?utm_source $=$ feedburner\&utm_medium $=$ email\&utm_campaign $=$ Feed $\% 3 \mathrm{~A}+\mathrm{P}$ atentlyO+\%28Dennis+Crouch $\% 27 \mathrm{~s}+$ Patently-O $\% 29$. 
At least some of these designs, notably the first, really do seem to be the driving force behind the sale of the product. Where that is true, applying the entire market value rule makes sense.

What reform would do is avoid crazy results like assigning a defendant's entire profit from the sale of a cell phone to the shape of a music icon. The patentee would be entitled to a royalty for the use of the icon, but not to use that tail to wag the dog. Calculating how much the icon adds to a smartphone won't be easy; reasonable royalty cases have struggled with these issues. But we know with complete certainty that "all the profits" is the wrong measure, so we can tolerate a fair bit of imprecision in estimating royalties and still be better off under an apportionment regime than we are today.

The statutory solution is "easy" only in the conceptual sense. It will require persuading Congress to Act, and that's always an uphill battle. But it is the right thing to do, and a verdict like Apple v. Samsung may be precisely the catalyst needed to bring design patent damages from the nineteenth century into the twenty-first. 
